\title{
Social Technology and Development in Telêmaco Borba/BRAZIL from the Social Network Analysis (SNA)
}

\author{
Heloísa de Puppi e Silva', Christian Luiz da Silva², Cleverson Vitorio Andreoli², \\ Cristina Maria Souto Ferigotti ${ }^{4}$
}

\begin{abstract}
This article observes the relationship among economic activity and local agents, by means of Social Networks Analysis (SNA) and showing the historical aspects on local development of the town of Telêmaco Borba, in the State of Paraná, Brazil. The social network can be understood as a Social Technology shaped by relationships among local agents and mapped by SNA. The relevance is given by the enrichment of knowledge by SNA, focusing on understanding the social technology as the basis of strategic formulation for actions to local development. The method used exploratory research and data from primary sources of a structured questionnaire for interviews. The study reveals that the interaction network among agents is elemental to creating capacities to its own identity and innovative solutions for local development. Pulp and paper activity is a cultural landmark and establishes a reference hard link and dependence for local actors.
\end{abstract}

Keywords: social technology; local development; social network analysis (sna).

Programa de Pós Graduação em Tecnologia (PPGTE) da Universidade Tecnológica Federal do Paraná (UTFPR).

'Address: 173, Raquel Prado Street - Mercês - Curitiba-Paraná-Brazil. ZIP Code: 80.5I0-360. Phone: +55 4I $3335-8528$. E-mail: helo_puppi@hotmail.com.www.fae.edu

${ }^{2}$ Address: 3165, Sete de Setembro Avenue - Rebouças - Curitiba-Paraná-Brazil. ZIP Code: 80.230-90I. Phone: +55 4I 33I0-47II. E-mail: christiansilva@uol.com.br.Websites: http://www.utfpr.edu.br

FAE Centro Universitário - Curitiba-PR-BR.

${ }^{3}$ Address: 1367, Engenheiro Rebouças Street - Rebouças - Curitiba-Paraná-Brazil. ZIP Code: 80.215-900. Phone: +55 4I $3330-3238$.

Fax: +55 4l 3333-9952. ${ }^{4}$ Adress: 135, 24 de Maio Street - Centro - Curitiba-Paraná-Brazil. ZIP Code: 80.230-080. Phone: +55 4I 2I05-4I55. 


\section{Introduction}

Klabin is an integrated pulp and paper producer in Brazil over a hundred years. In the State of Paraná operates in the region of Monte Alegre-PR approximately 75 years and led to foundation the "new town", which housed the first industrial plant workers. The allotment reached in 1963 a population approximately 34,400 (thirty-four thousand and four hundred) occupants, that conduced to the political emancipating and receiving the name of "Telêmaco Borba". In 2006, the company reached a production capacity of 710,000 tons per year of paper that represents $36 \%$ of the installed capacity of Paraná and 7\% in relation to Brazil (BRACELPA, 2008). The history of Telêmaco Borba's municipality is intertwined with Klabin because of its economic importance in the region. However, it is unclear how much this story influenced for the municipal development. Looking at the environment in which the company is entered is possible to extract relationships between their decision-making and the impact of these on location. It is assumed that a well-developed means provides better conditions of health, education, qualification, among others, both for workers and consumers of a company, thus forming a virtuous circle.

Local development comprehends the actions of the economic activity and of social welfare, the care for the environment, the preservation of spatial and cultural aspects that go through local agents, organized in networks. The social network can be mapped by Social Networks Analysis (SNA). SNA is a tool which checks the intensity of relationships and information flows. It's results allow the creation of local development strategies. The SNA is relevant as a model to observe social technology, explaining the relationship among local team and local development. SNA provides the conceptual, analytical and historical elements to answer the following question: Do the relations and interactions among the local actors and the pulp and paper activity have the capacity to promote local development?

Therefore, this study aims to observe, through the Social Network Analysis (SNA) the relationship between economic activity and the pulp and paper local development, based on Klabin and Telêmaco Borba-PR. The study helps to evaluate the importance of Klabin in the development of its surroundings and future strategies for the company and the municipality.

This is an exploratory research of deductive method with prior theoretical framework, contained in the first section, in Local Development, Economic activity and the role of the State. The second section addresses company history parallel to the history of the municipality and highlights the main relationships between Klabin and the development of Telêmaco Borba. Such relationships were established through documentary and bibliographic survey of secondary data. The next phase of the study consisted in the structuring of relationships by SNA in the town of Telêmaco Borba and its relation with Klabin through field research and data from primary sources by structured questionnaire for structured interviews with local actors as an empirical observation. Twelve interviews were conducted with Municipal Government departments, associations, trade unions and the Faculty of Telêmaco Borba. To contextualize the social network was used secondary data from documents on the company's website and books dealing with the history of Klabin and the municipality. The Social Network Analysis was based on sustainability and local development theories to characterize the institutions in terms of their structural and positional properties. An important characteristic of SNA was to try to assess the structure of relationship among social actors.

\section{Local Development, Economic Activity and the Role of the State}

The actions to promote local development can be influenced by economic activity or not. Individuals influence directly and pointedly in the directions, means and methods of life, as well as directions, means and methods of organization of each dimension. On the other hand, receives the influence of the corporate activities. Only local characteristics are able to generate the development (DE PUPPI E SILVA, 2008).

The cities are in the pursuit of sustainability solutions, because they are complex and able to initiate changes in their own delimitations (SASSEN, 1998). Communication and interaction at the local level are more effective and are according to their realities. The framework available as, for example, the urban facilities are essential to ensure access to development and create the necessary conditions in place for such (SILVA, 2006).There are agents of local development actions, such as cooperatives, development agencies, industrial and commercial associations, business entities, unions, local governments, among others (DE PUPPI E SILVA, 2008).

Local underdevelopment is not only related to price and distance problems. The whole place has elements, such as: men, institutions, businesses, infrastructure and the ecological support. These elements cannot be isolated in the analysis of local development. The solution to the problems of poverty depends on the knowledge of their training process as a whole. The capital is not evenly distributed in space and this raises dependency relationships. "Demand should adapt to the real needs of the population, within the limits of the social product. The production must organize itself according to the social demand so set." and is the State who should think about how to use the surpluses generated in order to achieve this goal (SANTOS, 2007, p. 157). 
The history of a place is made up of both local elements and extra places, resulting from the dissemination and propagation of races, languages, religions, cultivated plants, animals, way of life, new techniques, among other variables. Many spatial issues require historical study for understanding how they arrived and where they are (SANTOS, 2007). The history of companies goes beyond the description of the facts and experienced by organizations. Porter in his studies of competitiveness has already defended this relationship: "the essence of the formulation of a strategy is to relate a company to their environment." (PORTER, 1987, p. 22).

In addition, the emergence of urban facilities and institutional asset takes place according to local need. Other elements that arise with the concentration of the population and their needs are: press, radio, urban infrastructure, transportation, electricity and telecommunications, among others. The economic agents are heterogeneous because occupy different places in different spaces. In the same way that companies choose different places to settle down, the consumer behavior also depends on choices on the options available to them. To understanding local economic development requires the understanding of the local authorities, which consist of social actors and its specific practices. They are the political organization of space, with specific space management, public management, municipal governed alliances and local, State and national interactions (DE PUPPI E SILVA, 2008). It is necessary a definition of the characterization of the space according to each reality. In this way it is possible to understand the local reality, and relations between the agents, their roles and functions, and these elements align with the strategy and the search for solutions and overruns of underdevelopment.

According to the Constitution (BRASIL, 1988), the State must offer minimum infrastructure to the population. It is one of the enablers of the development and is present in all sizes reported in the previous chapters of this book. When the business organizations act in social responsibility, they take a strategic and administrative positioning. "the Administration is the process of planning, organizing, directing and controlling the use of resources to achieve goals." (CHIAVENATO, 1999, p. 6). The local perception about an action of social responsibility is intertwined with the same perception of the local about a public policy. The perception of the site confuses the origin of an action, not distinguishing the private and the public action (DE PUPPI E SILVA, 2008).

\section{Local Development and Social Technology}

The technology is a vitally important aspect to the human condition (MACKENZIE andWAJCMAN, 1996). The authors draw attention to the understanding that society, economy and politics determine the technology, because are inherent in it. Among the three elements, the economic reasons as the most relevant to the local development process, in this study, because they are linked to economic power.

Dagnino (2004) differs from the technology as follows: conventional technology that is used for the welfare of companies on the basis of profit is not efficient to promote social inclusion. So, the conventional technology is: "functional for the private company that, in capitalism, is responsible for "transform" knowledge into goods and services; Central governments support their development; Organizations and professionals that conceive are immersed in the social and political environment that legitimizes and demand; Because they bring with them their values and, therefore, to reproduce." (DAGNINO, 2004, p. 9).

While the social technology is: "Adapted to small physical size and financial; Non-discriminatory basis (boss $\times$ employee); Internal market-oriented mass; Liberating the potential and creativity of direct producer;Able to make economically self managed enterprises and small businesses." (DAGNINO, 2004, p. 7).

In this sense, it is possible to understand that the recognition of a network shaped by relationships by a tool enables the elements cited by Dagnino (2004). But for this understanding, should also be included the public company and institutional assets, that is, the various types of organizations and the network of relationships established by the company.

Social networks are the central structure for the dissemination of information and knowledge. In the context of innovation, networks can be identified under different settings: regional industrial networks, inter-organizational professional networks (DE BRESSON and AMESSE, 199I). The network functionality is based on the principles of complementarity and reciprocity. This means that firms will participate in these networks, if the expectation to learn from other members (complementarity) and the transfer of knowledge is bi-multilateral or multilateral (reciprocity) (DE BRESSON and AMESSE, 1991). However, the physical interaction occurs between individuals, affecting them in the context of disseminating knowledge and information (KOGUT and ZANDER, 1995) (SORENSON, 2003), despite that configure networks are arrangements between organizations.

While the complementarity may exist between activities in different fields of technology, many authors argue that partnerships for cooperation require some level of technology to superimpose, in order to facilitate the exchange of knowledge and joint development (MOWERY et al., 1998) (CANTWELL and BARRERA, 1998) (CANTER and GRAF, 2004). Technology is here understood as in Figueiredo (2009), this is as shaped, developed and changed within 
organizational contexts. These are located within regional and national contexts. Therefore, the technology shaped in local by a structured social network, from the Foundation of the company Klabin, is a relevant role for Telêmaco Borba-PR muinicipality.

Among the company's partners for the development of knowledge, including universities and Institutional Assets as SENAI (National Industrial Training Service), and each partnership range and its position in the value chain, their level of sophistication, resources committed and experiences with alliances (POWELL et al., 1996) represent the institutionalized way worldwide for knowledge transfer. On the other hand, the importance of the firm within the social network format, their collaborative actions and choice of partners is evidenced in the study of Gulati (1998). To be mutually beneficial cooperation, both partners need to absorb the ability to learn with one to another (COHEN and LEVINTHAL, 1990), the authors understand the absorption capacity as the overall capacity of the individuals, groups, and company recognize the value of the new information, choosing to embrace it and apply it to innovation.

The impact of organizations in their own development and in local development is possible only from the knowledge of the network. Thus, the Social Networks Analysis (SNA) allows such understanding among the relationships and interactions of local staff, featuring the local social network structured as a social technology.

\section{Klabin's History and Telêmaco Borba-PR-BR: the main relationships and Local Development}

The survey results showed that the town of Telêmaco Borba, founded in 1964, arose from a gradual evolution of economic and social activity, from the installation of Klabin in 1934. The history of the town of Telêmaco Borba is divided into two phases: before the opening of the lands of Klabin and after opening of Klabin's lands. The formation of the municipality and the local social and economic relations are related to the presence of Klabin. In addition, over the years the economic, social and environmental activity intensified on site and with it also intensified the partnership between Klabin and agents of development, local, regional and national, to ensure the well-being of the local population (DE PUPPI E SILVA, 2008). The company settled on the Monte Alegre farm due to political relations, political interests, economic interests, to guarantee improvements of infrastructure and the proximity of the raw material, wood and water. The local economic activities have had the beginning with Klabin's activity and intensified when the company chose to sell lots on their land to interested in settling on the site, because the company had no forces, not even by your private land property to contain the people (FERNANDES, 1974).
Although Klabin be related to a competitive national and global dynamics, the beginning of a local activity was inevitable for leisure, health, safety, housing, education, communication and housing conditions of the local population, which has been expanding over the years by the establishment of families of employees and other local residents. While Klabin had control to make the turns of the State (income, food, health, safety, leisure, education, communication, supply and sanitation, housing, transportation) in its private property, the company did it.

Under an observation of relationship of pulp and paper activity with local development: pulp and paper activity, despite being vertical, resulting in a positive impact on local development, to stimulate other activities and income generation; Pulp and paper activity is local cultural landmark setting a hard link and dependence; Pulp and paper activity, by the use of forests, occupies $95 \%$ of the land in the city leading to the understanding that solutions and alternatives need to be designed for the urban space; Pulp and paper activity uses up natural resources and must be in constant control over the pollution generated by their activity; and pulp and paper activity influences the social environment of the site with regard to social classes and to meet the health, education, welfare and infrastructure. Therefore, the swelling population caused by the attractiveness of the offer of employment by the company's strategies aggravate the problems related to these issues, impacting negatively on local development. However, Klabin provides historical cultural relations in the municipality and, therefore, as a topic for future studies, to emphasizing the need to interview the population and determining their perceptions regarding the company.

\section{Apparatus and Procedure for Recent Relations between Klabin and Telêmaco Borba-PR-BR}

Whereas the local agents, represented by individuals and organizations, are structured in networks through their interactions and interdependence, resulting in somewaht for local development, this section aims to complete the verification between Klabin's relations and Telêmaco Borba's municipality and how these interactions contribute positively or negatively to the local development. In order to respond to the problem of this research, Social Networks Analysis (SNA) was used to structuring a network of links between the local actors, by observation of partnerships and even observing if these relations, their intensities and benefits impact positively or negatively on the development of Telêmaco Borba, to characterize the social network structured as a social technology, potential for local development actions targeting.

The use of this tool is justified for given the advancement of analytical solutions of the simultaneous treatment of social 
structure and action (TILLY, 1992 apud MARQUES, 2006). When discussing the applicability of analysis network discusses the articulated set of actors, institutions and relationship patterns, as well as the way in which these factors affect each other complex, still not understood, with regard to networks (MARQUES, 2006). Also deals with the understanding that such networks vary according to the context in which they are inserted and that these have historically dynamic structures built and transformed over the years.

The networks are composed of nodes, represented by social agents, according to sociology, and the links between these nodes, represented by some sort of relationship. In this way analysis can be used to observe information flows. The links between the nodes, represented by the actors, can independent support the origin of those (SILVA, 2006). While, otherwise, emphasizes the origin of such actors as an historic element analysis (MARQUES, 2006). To this end it is necessary to establish some elements to application of method, in accordance with the phenomenon observed and the answer to the question research.

The Social Network Analysis is used to study the development, based on institutional trends, initiatives that define the field of agents to not overlapping efforts on actions, relations between the Organization and the local community, among others. There is need to establish local actors, namely, the central actors for which the field search will start. In this sense, turns out the attention and the participation of these actors in local development. It is also considered that although the actors make decisions, these can be perceived in different ways by the network.

In the design of social network, people, institutions and organizations represent the nodes. The relationships between the actors, among the nodes, are represented by the existing links. The actors can be organized into groups according to their attributes. To define the groups of local actors is necessary to define the attributes, which represent the distinct characteristics of the groups, as for example, the economic activity, educational level, the ownership of income, among others. In this way, about the attributes, it aims to identify the different types of actors that participate in the network. However the links express the different types of relationships and are related to the information wanted by the constitution of the social network. On the lookout for: the relationships wanted to measure, the relationship between which actors, the types of information that flow in networks, the media used for the contact between the actors, among other research needs.

The Social Network Analysis, when looked at the links, result in indicators such as: number of times the actors communicate for a period of time, that can measure the intensity of relations; confidence in the relationship; the use of the information; the types of information, among other indicators. In accordance with the parameters established, in one way or another of usage and verification of links, is necessary to assign values that should be considered to measure the strength or intensity of the links.

\section{Results of Social Network Analysis (SNA) Field Research on Social Technology and Local Development}

Between 2006 and 2008, Klabin made its expansion project and, traditionally, received the visit of the Brazilian President to his inauguration. At the time, the Mauá hydroelectric power plant was starting his works by the growth acceleration program (PAC) of the Federal Government. Telêmaco Borba lived the expectations of the municipal elections and was preparing for the construction of the Regional Hospital of Telêmaco Borba, by State Government programs. The municipality was also getting investment for the installation of the Federal Institute of Education, Science and Technology (IFET). In previous years, the municipality also received investments of new firms in the industry of wood and pulp and paper. The outskirts of the city is the area of greatest weakness with regard to outstanding development issues of poverty, drugs, crime, health, among others. It is worth mentioning that the urban region of Telêmaco Borba has nowhere to grow, whereas $93 \%$ (ninety-three percent) of the land in the municipality belong to Klabin's forests. This data was changed in accordance with the master plan of the municipality, since before this percentage was $95 \%$.

In the city there is the pride in being a pioneer and the respect to whom it is, the first Pioneers, whose are people that resided in Telêmaco Borba before their emancipation. In accordance with the report of the interviewees, culturally, the population thinks everything is in Klabin's function. Everything that happens in the city, whether or not they are impacts of Klabin's action, are considered by the population as 'Klabin's things '. In other words, what happens, good or bad, ' it was Klabin's action'. On the other hand, people who are linked to the actions of other institutions are aware that Klabin is very strong in the city, but there is a lot that is done without their dependency or relationship. Consider that in earlier times the dependence of the municipality was much higher the shares of the company, but that today the municipality already walks in parallel, but still greatly influenced. The institutions interviewed, representing the local agents, in Telêmaco Borba since 1957. From the thirteen agents interviewed, three founded in the 1960's, one in the 1970's, one in the 1980's, two in the 1990's and four in 2000's. It is observed, therefore, the recent Foundation of agents. The origin of seven agents is related to people from Telêmaco Borba. Other agents have two origin related to people from 
other cities and three agents settled by people from Telêmaco Borba and other cities.

As to the relationship of local institutions, twelve agents were interviewed. Four agents had its Foundation related to Klabin, Five related to prefecture, and three agents settled because other agents, that had its foundation by the need of the organization of the working class and the local shops. Even the latest facilities are related to Klabin. According to the interviews, the actions in partnership have been intensifying in recent and current partnerships made from four years ago are more numerous, even because, relate to the last Municipal Government management.

Figure I presents the existing links between the agents interviewed. The Telêmaco Borba City Hall, represented by their Secretaries, had the highest number of links, with agents that are also related to other agents on the site. This network offers any type of relationship between the agents regardless of partnerships. The SINDIMATEL does not have relations with other agents interviewed, although his contact has been obtained by interviewing SINTRACON.

Figure 2 presents the structured network with all partnerships and reported by respondents. The institutions that have a higher number of links are: City Hall (17), the Municipal Secretary of culture, sport and recreation (16), Municipal Secretary of Social Action (10), Municipal Secretary of health (8), COTEPAM (8), ACITEL (8), Klabin (8), FATEB (7) and the other institutions with 6 or fewer links. This network (Figure
2) shows the centrality set by the city hall and by the Secretary of culture. Measured by the degree centrality that has the following definition: "It is the feature that identifies the number of direct contacts that an actor keeps on a network, that is to say, it is what measures the level of communication of an actor." (TOMAÉL; MARTELETO, 2006, p.79).

For verification and confirmation of the results, two others social networks were structured with different methodologies described in note. First, in the case of the distance between the local actors, it was used the multiplication of addiction by benefit, other calculation methodology. In this calculation was considered the multidimensional scale for GEODESIC distance, which until then had not been made. However, the calculations were based on the Multivariate Analysis. Both Klabin and City Hall are very close and in the center of the network. Then, they measured the distances between the agents based on metric multidimensional scaling of Gower (main coordinate analysis), which reduces the dimensionality that disregard low values of variability (MOREIRA, 2006). That means, the distances in this network, eliminate the variability obtained by multiplying by the dependency benefit, establishing the distance with lower intensity of involvement. However, the measure of centrality of this network remained the same that considers the variability of benefits by dependencies. From these considerations the City Hall is again the center of the network (away), both City Hall and Klabin establish the centrality (size of circle) of the model. However, the results obtained by Figure 2 are confirmed in Figure 3.

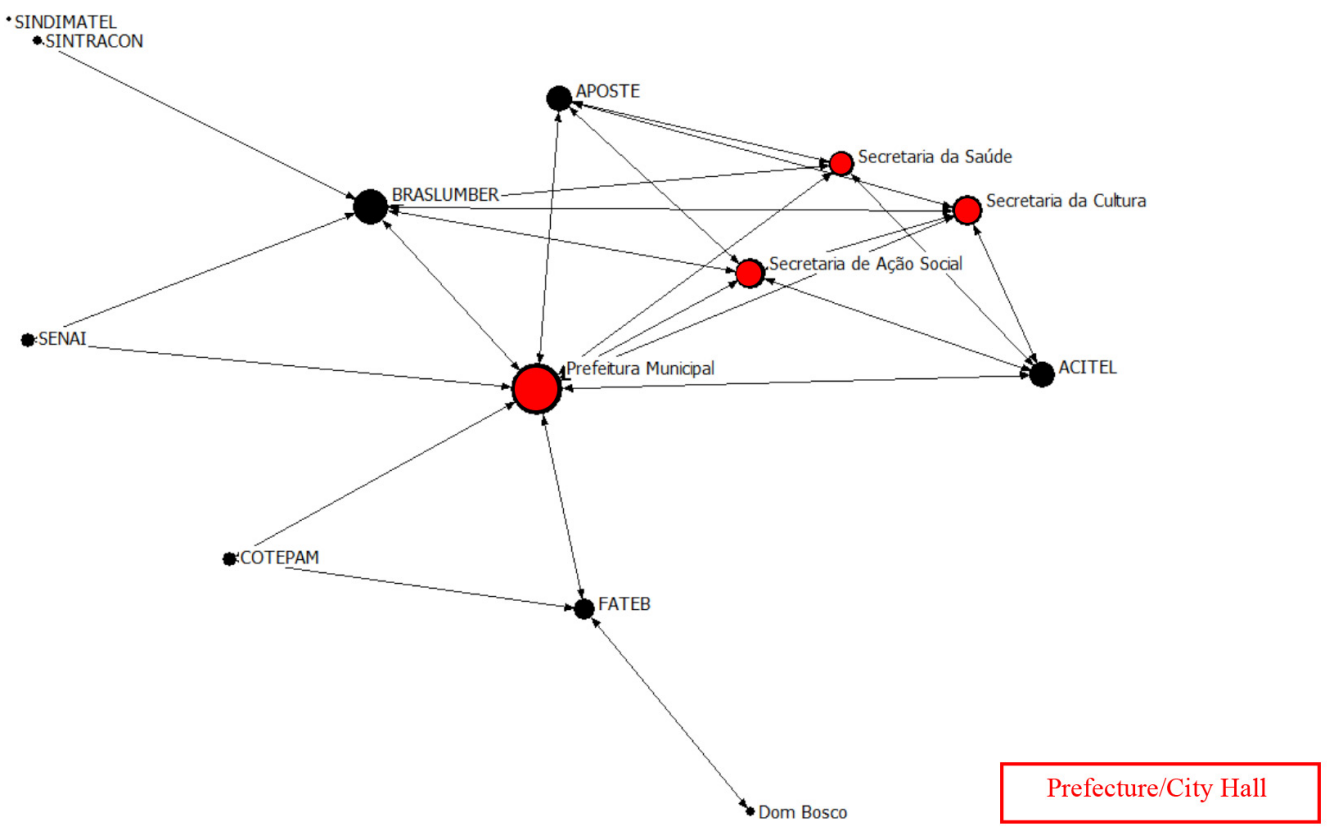

Figure I. Links between local actors interviewed; centrality measure by degree. Data from field research, tabbed by the author. Note: used the software Ucinet 6

ISSN: 07I 8-2724. (http://www.jotmi.org) 


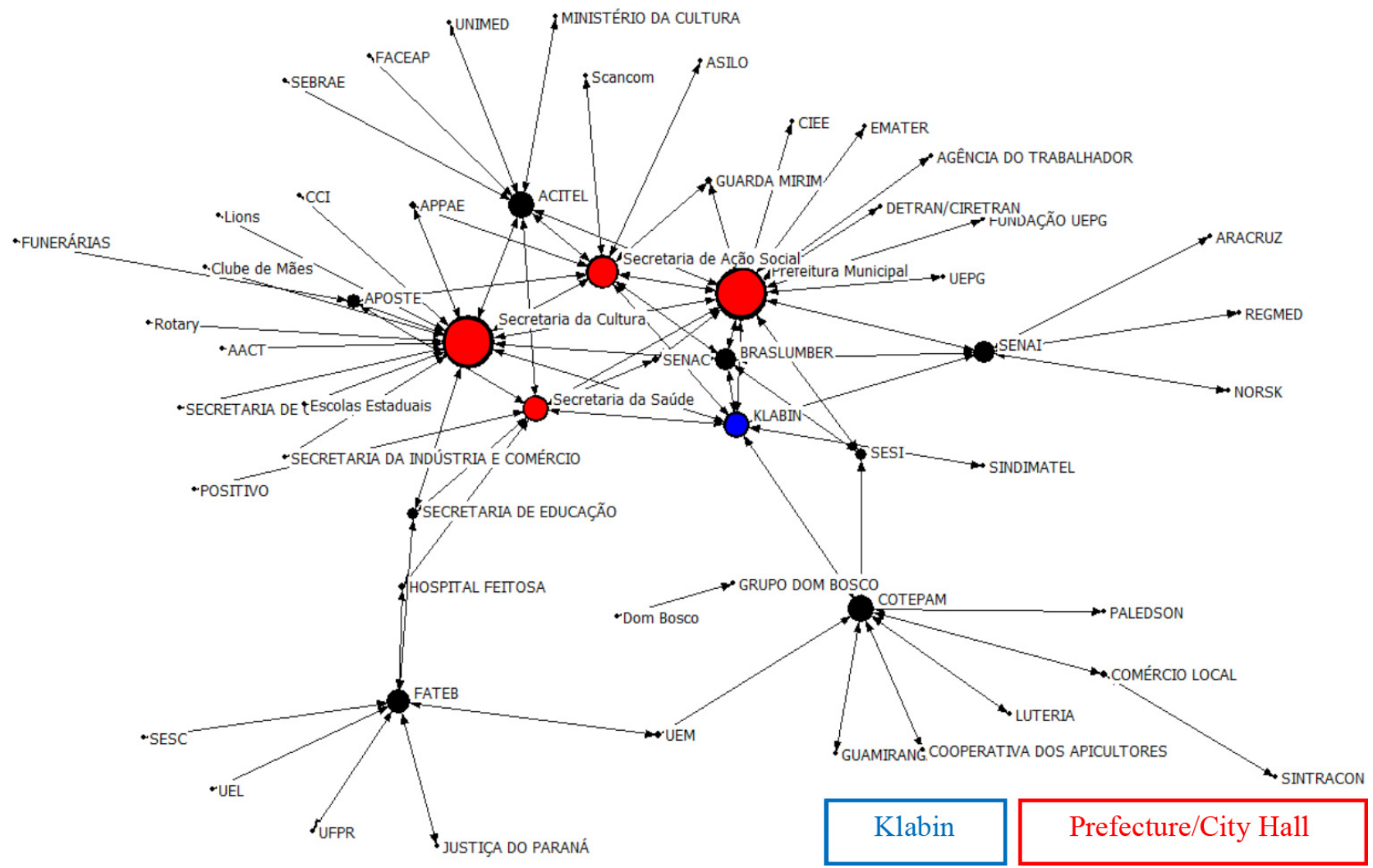

Figure 2. Partnerships between local actors; centrality measure by degree. Data from field research, tabbed by the author. Note: used the software Ucinet 6



•Dom Bosco

Klabin

Prefecture/City Hall

Figure 3. Intensity (and dependency benefit) and intensity of relations singled out in partnerships between local actors; centrality for eigenvectors. Data from field research, tabbed by the author. Note: used the software Ucinet 6

ISSN: 07 I8-2724. (http://www.jotmi.org)

Journal of Technology Management \& Innovation (c) Universidad Alberto Hurtado, Facultad de Economía y Negocios. 


\section{Discussion}

Despites being vertical, Pulp and paper activity results in positive impacts to local development, as stimulate other activities and income generation. The activity is a local cultural landmark setting a hard reference link and dependence. Klabin occupies $95 \%$ of the land in the city leading with its forests, leading to the understanding that solutions and alternatives need to be designed for the urban space. The company must be in constant control over the pollution generated by its activity for the uses up natural resources. Therefore, the pulp and paper activity influences the social environment of the site with regard to social classes and to meet the health, education, welfare and infrastructure. The swelling population, caused by the attractiveness of the offer of employment by the company's strategies, aggravates the problems related to these issues, impacting negatively on local development.

By enabling understandings of local staff on their roles, relationships and interactions to Local development, the Social Network Analysis (SNA), revealed, preliminarily, that social networking, structured from the Klabin's installation, can be exploited as a social technology. But, this is still likely to expand in other studies.

From the SNA, it was observed that in recent years, have been taking place the dimming of the dependencies for local agents in relation to the company, even if the links are still very intense. This implies that the understanding that reducing dependence is positive because unlinks the survival of agents to Klabin's survival. Relations among agents are numerous and the centrality tends, in many cases, to City Hall. But, still remains as the challenge, intensify relations that are not performed with Klabin, so that the efforts for development to meet the aspirations of the entire population.

The SNA revealed the vulnerable aspects of local development, which are the unexpected impacts caused by enlargements of Klabin. Local officials reported that why they cannot meet the population increase in social issues, education and health. In other words, Klabin impacts negatively in the municipality with respect to local development, since the expansion interfered and created obstacles in the actions, in partnership or not, performed by local actors for development. In other words, Klabin triggers negative impacts to social issues when don't plan together with the municipality their expansion projects. Despite making responsibility actions, these are not sufficient to counterbalance the negative impacts of population attraction caused by the company. Among the negative impacts are the increase in the cost of living, the difficulty of access to social services and increasing crime.
The study of network still showed that the measurement of the interaction between the agents and the local development are fundamental to the creation of its own identity and solutions for local development. Although the measurement by quantitative indicators is limited, qualitative indicators of intensity and of interactions among agents involved expressed.

However, Klabin provides historical cultural relations in the municipality and, therefore, as a topic for future studies emphasized the need to interview the population and determine their perceptions regarding the company. It is also possible to enlarge the universe interviewed in this study to deepen the perceptions on the relationship of dependence of Klabin and other agents of the municipality.

\section{References}

BRACELPA (Associação Brasileira de Celulose e Papel) (2008). Informações gerais sobre o setor 2007. URL: <http:// www.bracelpa.org.br/bra/index.html> Date Acess: august $/ 2008$.

BRASIL (1988). Federal Constitution, 1988.

CANTNER, Uwe and Graf, Holger (20I I), Innovation Networks: formation, performance and dynamics, in: C.Antonelli (Ed.), Handbook on the Economic Complexity of Technological Change, Ch. I5, Edward Elgar, Cheltenham UK.

CANTWELL, J.A. and Barrera, M.p. (1998), 'The localisation of corporate technological trajectories in the interwar cartels: cooperative learning versus an exchange of knowledge', Economics of Innovation and New Technology, vol. 6, pp. 257-290.

CHIAVENATO, Idalberto (1999). Introdução à Teoria Geral da Administração: edição compacta. 2ed. Rio de Janeiro: Campus.

COHEN, W. M., Levinthal, D. A. (1990). Absorptive capacity: a new perspective on learning and innovation. Adminstrative Science Quarterly 35, I28-I52.

DAGNINO, Renato (20ll). A tecnologia social e seus desafios. 2004. URL: http://www.ige.unicamp.br/site/ publicacoes/ I 38/A\%20tecnologia $\% 20$ social $\% 20$ e $\% 20$ seus\%20desafios.pdf Date Acess: 03/2I/20I I.

DE BRESSON, C. and Amesse, E. (1991). Networks of innovators: a review and introduction to the issue. Research policy $20(5), 363-379.1991$ 
DE PUPPI E SILVA, Heloísa (2008). Sustentabilidade e Desenvolvimento Local a partir da Atividade Econômica de Celulose e Papel:Telêmaco Borba e a Klabin em questão. Curitiba, 2008. Dissertação de Mestrado do Programa em Organizações e Desenvolvimento da FAE - Centro Universitário. URL: http://www.fae.edu/mestrado/dissertacoes2006.vm Date Access: 2010.

FIGUEIREDO. P.N. (2009). Gestão da inovação: conceitos, métricas e experiências de empresas no Brasil. Rio de Janeiro: LTC.

FERNANDES, Hellê Vellozo (1974). Monte Alegre: cidadepapel. Klabin do Paraná.

GULATI, R. (1998). Alliances and networks. Strategic Management Journal 19 (4), 293-3I7.

MACKENZIE, Donald and Wajcman, Judy (1996). Introductory essay and general issues. In:The Social Shaping of Technology. Buckingham, Philadelphia: Open University Press.

MARQUES, Eduardo Cesar (2006). Redes Sociais e Poder no Estado Brasileiro: Aprendizados a partir das políticas urbanas.

MOREIRA, José Antonio (2006). Mapas Perceptuais e Variações na Participação de Mercado. São Paulo, 2006. 166p. Dissertação (Administração de Empresas) Escola de Administração - Fundação Getúlio Vargas (FGV).

MOWERY, D. C., Oxley, J.e., Silverman, B. S. (1008). Techonolgy overlap and interfirm cooperation: implications for the resource-based view of the firm. Research Policy 27(5), 507-523.

POWELL, W.W.,Kogut, K.w., Smith-Doerr, L. (1996). Interoganizational collaboration and the locus of innovation: Networks of learning in biotechnology. Administrative Science Quarterly 4I (I), I I6-I45.

PORTER, Michael E. (1987). Estratégia competitiva. Ed. Campus.

SANTOS, Milton (2007). Economia espacial. São Paulo: Editora da Universidade de São Paulo.

SASSEN, Saskia (1998). Os espaços da economia global. In: Oliveira, F. A. M. (org.). Globalização, Regionalização e Nacionalismo. São Paulo: Unesp.

SORENSON, O (2003). Social networks and industrial geography. Journal of Evolutionary Economics 13, 5I3-527.
SILVA, Christian (Org.) (2006). Desenvolvimento Sustentável: um modelo analítico integrado e adaptativo. Petrópolis-RJ : Vozes.

TOMAÉL, Inês Maria; Marteleto, Regina Maria (2006). Redes Sociais: posições dos atores nos fluxos de informação. Enc. Bibli: R. Eletr. Bibliotecon. Ci. Inf., Florianópolis, n. esp., I ${ }^{\circ}$ sem. 2006. URL: http://www.periodicos.ufsc.br/index.php/eb/article/viewFile/342/387 Date Access: September/2008.

ZANDER U. and Kogut, B. (1995). Knowledge and the speed of the transfer and imitation of organizational capabilities: an empirical test .Organization Science 6, 76-9I. 